\title{
SURVEY OF GASTROINTESTINAL PARASITES OF THE CENTER FOR SCREENING OF WILD ANIMALS FROM SÃO LUÍS, MARANHÃO STATE, BRAZIL
}

\author{
PESQUISA DE PARASITOS GASTRINTESTINAIS DO CENTRO DE TRIAGEM DE ANIMAIS \\ SILVESTRES DE SÃO LUÍS DO MARANHÃO, BRASIL
}

\author{
M. A. P. FIGUEIREDO ${ }^{1 *}$, W. G. MANRIQUE ${ }^{2}$, R. M. S. NOGUEIRA ${ }^{3}$
}

\begin{abstract}
SUMMARY
The objective was to identify the gastrointestinal parasites of wild animals received by the Center for Screening of Wild Animals from São Luis, Maranhão State, Brazil. The fecal samples were collected from 297 animals, of which 150 (50.5\%) were birds, $132(44.5 \%)$ mammals and $15(5 \%)$ reptiles. A total of 262 samples (227 individual and 35 pools) were analyzed by the method of sedimentation and flotation, 102 animals were parasitized by helminthes and/or protozoa, 39 of which belonged to the order Primate, 18 to the Carnivorous order and 12 to the Psittaciformes order. The mammals had the greatest diversity of eggs of gastrointestinal parasites: Strongyloides sp., hookworm type, Spirometra sp., Ascaris sp., Trichuris vulpis, Capillaria sp., Strongyloidea, Ancylostomidae , taenid and oocysts of coccidian. In the samples of birds were diagnosed eggs of the genera Dispharynx, Ascaridia, Echinostoma and oocyst of coccidian. In the reptiles, the number of gastrointestinal parasites was low, being identified oocyst of coccidian in three jiboia (Boa constrictor) and Capillaria sp. in an iguana (Iguana iguana). It was concluded that wild animals act as hosts for various species of parasites and to establish the dynamics and parasitic fauna of these animals at the screening center is an excellent alternative for studies ex situ.
\end{abstract}

KEY-WORDS: Coproparasitology; Endoparasites; Helminths; Mammals; Reptiles.

\section{RESUMO}

Objetivou-se identificar os parasitos gastrintestinais de animais silvestres recepcionados pelo Centro de Triagem de Animais Silvestres de São Luís, Maranhão. As amostras fecais foram coletadas entre agosto de 2006 a julho de 2008 , totalizando 297 animais, dos quais 150 (50,5\%) foram aves, 132 (44,5\%) mamíferos e 15 (5\%) répteis. Do total de 262 amostras (227 individuais e 35 pools) analisadas pelo método de sedimentação simples e flutuação, 102 animais estavam parasitados por helmintos e/ou protozoários, sendo que, 39 pertenciam à ordem Primata, 18 à Carnívora e 12 à Psittaciforme. Os mamíferos apresentaram a maior diversidade de ovos de parasitos gastrintestinais, como Strongyloides sp., ancilostomídeo, Spirometra sp., Ascaris sp., Trichuris vulpis, Capillaria sp., Strongyloidea, Ancilostomídeo e tenideos, além de oocistos de coccídios. Em amostras de aves identificaram-se ovos dos gêneros Dispharynx, Ascaridia, Echinostoma, e também de oocistos de coccídeos. Nos répteis, o número de parasitos gastrintestinais foi baixo, sendo identificados oocisto de coccídeo em três jiboias (Boa constrictor) e Capillaria sp. em uma iguana (Iguana iguana). Concluiu-se que animais silvestres atuam como hospedeiros para diversas espécies de parasitos, e estabelecer a riqueza e a dinâmica da fauna parasitária desses animais nos centros de triagem é uma excelente alternativa para a realização de estudos ex situ.

PALAVRAS-CHAVE: Coproparasitologia; Endoparasitos; Helmintos; Mamíferos; Répteis.

\footnotetext{
${ }^{1}$ Universidade Federal de Rondônia (UNIR), Rolim de Moura-RO. Email: mayra.araguaia@unir.br

${ }^{2}$ Universidade Federal de Rondônia (UNIR), Rolim de Moura-RO. Email.: wilson.gomez@unir.br

${ }^{3}$ Universidade Estadual do Maranhão. Email.: ritam@ hotmail.com
} 


\section{INTRODUCTION}

Brazil takes part of the sixth countries with the richest biological biodiversity (Lewinsohn; Prado, 2002). Due to its importance, surveys on wild fauna in Brazil have been conducted not only to minimize the macroscopic ecological imbalance caused by the historical withdrawal of these animals from its natural habitat but also because the microscopic imbalance that can be caused by internal parasitic fauna. The parasitic fauna have an wild cycle and could have an urban cycle too that same times can have impact on public health (Mackenstedt et al., 2015) such as leishmaniosis, Chagas' disease and hydatidosis (Alexandre, 2000). However, studies on parasitic fauna in wild animals should not be restricted to its role as reservoirs of zoonotic diseases but also as a means of conservation and maintenance of biodiversity (Thompson et al., 2010).

Studies have demonstrated that infection by parasites can have severe effects on the survival and reproduction of the host species, therefore elaborate efficient protocols to maintain health and genetic diversity must be a priority (Scott, 1988), especially regarding wild species.

Important methods to study the parasitic fauna of wild animals are the fecal exams of the hosts by searching for parasite eggs, cysts, oocysts and larvae (Vieira et al., 2006). These methods are quick, cheap and non-invasive. The relevance of the research on parasitic fauna is recognized and required in reintroduction protocols (UICN, 1998; Felasa, 1999) and also in the clinic routine of wild animals.

Though authors believe the captivity condition is a disadvantage for a great varied of parasites since the source of infection are more limited than in free life, in a general way, wild animals housed in captivity are more susceptible to infectious and parasitic diseases (Freitas et al., 2001; 2002), specially due to the inadequate hygiene of the accommodations (Marietto-Gonçalves et al., 2009). However, due to the stress of the captivity lived by these animals, they become susceptible to the actions of the parasitic fauna that until then lived in equilibrium with their host (Catão-Dias, 2003; Santos et al., 2015). Knowing that in free life the action of parasites on hosts also serve as population control of a species. Furthermore, parasite diversity can be an indicator of ecosystem health, as it reflects the stable relationships between parasites and hosts (Santana; Mesquita; Seixas Filho, 2014).

Taking into account the spread of the cities upon the wild environment and the participation of man in the parasite life cycle of wild animals (Lim et al., 2008; Li et al., 2015) it is necessary to perform studies on internal fauna of these animals to try to minimize the impact on public and animal health. Moreover, over recent decades, diseases have shown to be important causes of extinctions among wild species. Greater emphasis has been given to diseases transmitted by domestic animals, which has been increasing in numbers in natural areas, along with human populations (Santos et al., 2012).

There are few researchers on parasites of wild animals in the State of Maranhão, Brazil and the available information is restrict to external parasites (Guerra et al., 2000; Figueiredo et al., 2010). So the aim of this study was to report on the diversity of parasitic helminthes and protozoan in feces of wild animals received at Center for Screening of Wild Animals of São Luis, Maranhão (CETAS/MA).

\section{MATERIAL E MÉTODOS}

\section{Study area}

The study was performed in the Center for Screening of Wild Animals of São Luis, Maranhão (CETAS/MA) (256'80”'S, 44²1'01'O). CETAS belongs to IBAMA, the Brazilian Institute of Environment and Renewable Natural Resources, and has as primary activities to receive, take care, rehabilitate and give a destination of wild animals that were captured, rescued or spontaneously dropped off by the population. Therefore in great majority of the cases the origin of these animals is unknown

São Luis city is located at São Luis Island, northeastern of Brazil (Figure 1). The climate is tropical humid and temperatures vary between $26^{\circ}$ to $28^{\circ} \mathrm{C}$. There are two seasons well defined, the dry season from July to December and the rainy season from January to June. Rainfall index can reach above $2000 \mathrm{~mm}^{3}$. 


\section{Samples collection and fecal exams}

Fecal samples were collected during the entrance of the animals at CETAS, from August/2006 to July/2008 covering the dry and rainy seasons. The samples were collected early in the morning in canvas placed under the cages or enclosure of animals'. They were put on recipient per sampled animal or pools when the cage or enclosure had more than one animal.
The following methods for finding eggs, cysts, oocysts and larvae of parasites in the samples: flotation in saturated chloride solution (Willis, 1927) and sedimentation (Hoffmann et al., 1934). To visualize parasitic forms a light microscopic was used and the identification was done according to Soulsby (1968), Skryanbin (1969) and Yamaguti (1961).
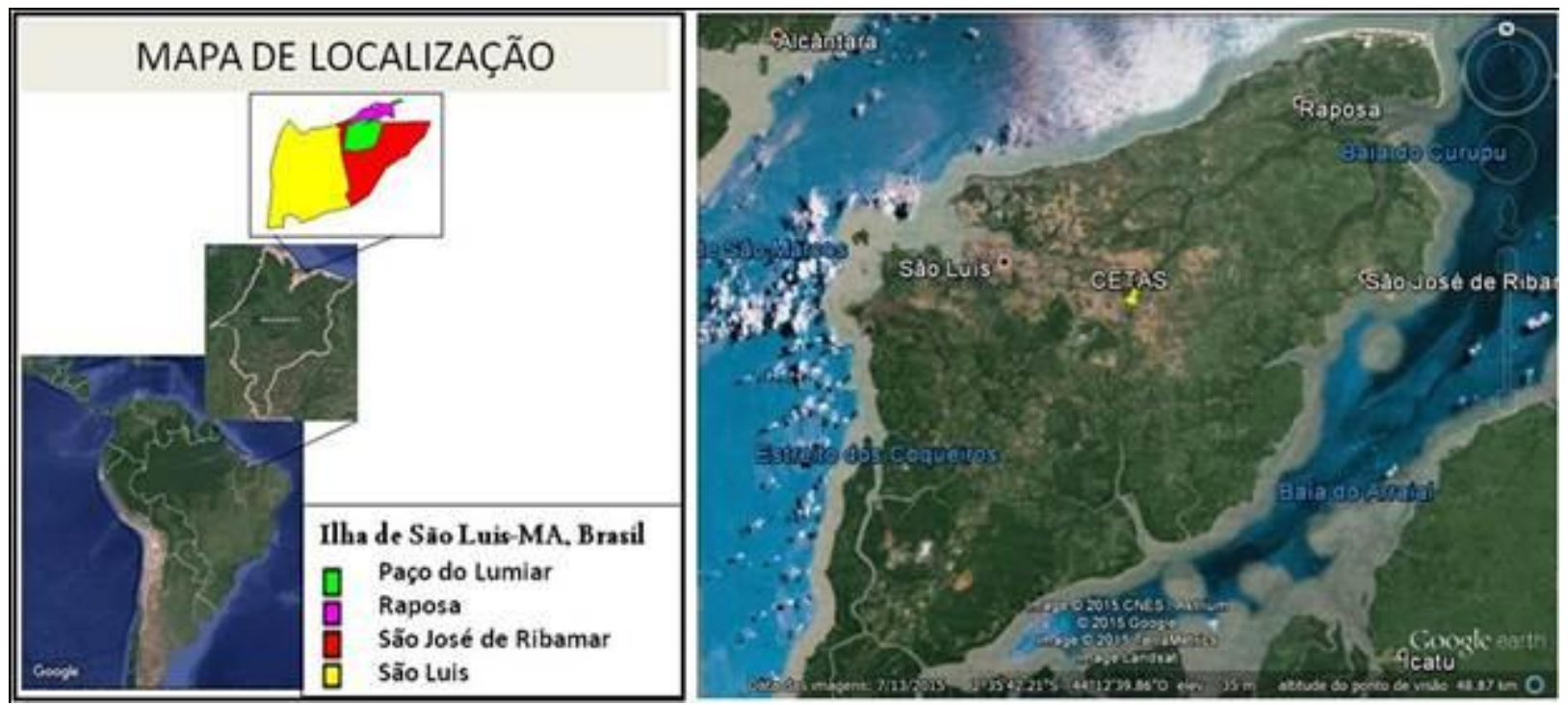

Figure 1 - Satellite image of Maranhão State, São Luis Island and Center for Screening of Wild Animals of São Luis, Maranhão (CETAS/MA). Source: MapInfo Professional 7.5 SCP; Google earth.

\section{RESULTS}

A total of 297 animals were sampled as follows: $15(5 \%)$ reptiles (Table 1$), 132(44.5 \%)$ mammals and $150(50,5 \%)$ birds (Table 2). A total of 262 fecal samples were analyzed being 227 individual samples and 35 pools. From the 297 animals, 102 (34.34\%) were infected by helminthes and/or protozoan, from these, $63(61.77 \%)$ were mammals, $35(34.31 \%)$ were birds and $4(3.92 \%)$ were reptiles. Same eggs identification only could be done until the taxon of superfamily.

Eggs of the following genera of gastrointestinal helminths were identified in birds: Ascaridia,
Dispharynx, Echinostoma. Coccidian oocysts were also detected. In the sample pools of Dendrocygna viduata, Amazona amazonica, Amazona aestiva and Ara maracana we detected oocysts of cocidian and eggs of Ascaridia sp. (Table 3). Mammals were infected by Strongyloides sp., eggs of the hookworm type, Spirometra sp., Ascaris sp., Trichuris vulpis, Capillaria sp. (Table 3). Eggs of taenid, Strongyloidea and hookworm type and oocyst of coccidian were also observed. In reptiles, the prevalence of gastrointestinal parasites was low. Coccidian oocystis in three $B$. constrictor and eggs of Capillaria sp.in a I. iguana were detected. The results are summarized in Table 3 .

Table 1 - List of reptiles sampled at the Center for Screening of Wild Animals of São Luis, Maranhão State (CETAS/MA), Brazil, from August/2006 to July/2008.

\begin{tabular}{cccc}
\hline Order & Family & Common name in English & Number sampled/Specie \\
\hline \multirow{2}{*}{ Squamata } & Iguanidae & Green iguana & 01 Iguana iguana \\
\cline { 2 - 4 } & Boidae & Boa constrictor & 12 Boa constrictor \\
& Chelonidae & Yellow-footed Tortoise & 01 Boa constrictor amarili \\
\hline Chelonia & &
\end{tabular}


Table 2 - List of mammals and birds sampled at the Center for Screening of Wild Animals of São Luis, Maranhão State (CETAS/MA), Brazil, from August/2006 to July/2008.

\begin{tabular}{|c|c|c|c|}
\hline Order & Family & Common name in English & Number sampled/Species \\
\hline \multicolumn{4}{|l|}{ Mammals } \\
\hline \multirow{5}{*}{ Primata } & \multirow{2}{*}{ Cebidae } & Tufted capuchin & 69 Sapajus apella \\
\hline & & Squirrel monkey & 07 Saimiri sciureus \\
\hline & \multirow{2}{*}{ Callithrichidae } & Common marmoset & 04 Callithrix jacchus \\
\hline & & Tamarin & 05 Saguinus midas niger \\
\hline & Atelidae & Black Howler & 01 Alouatta caraya \\
\hline \multirow{8}{*}{ Carnivora } & Canidae & Crab-eating fox & 03 Cerdocyon thous \\
\hline & \multirow{2}{*}{ Procyonidae } & South American Coati & 12 Nasua nasua \\
\hline & & Raccoon & 01 Procyon cancrivorus \\
\hline & \multirow{4}{*}{ Felidae } & Oncelot & 04 Leopardus pardalis \\
\hline & & Jaguarundi & 02 Puma yagouaroundi \\
\hline & & Margay & 02 Leopardus wiedii \\
\hline & & Northern Tiger Cat & 06 Leopardus tigrinus \\
\hline & Mustelidae & Lesser grison & 03 Galictis cuja \\
\hline Didelphimorphia & Didelphidae & Opossum & 02 Didelphis marsupialis \\
\hline Artiodactyla & Cervidae & Brown brocket & 01 Mazana gouazoubira \\
\hline Rodentia & Agoutidae & Spotted paca & 03 Agouti paca \\
\hline \multirow[t]{2}{*}{ Xenarthra } & Myrmecophagidae & Southern tamandua & 02 Tamandua tetradactyla \\
\hline & Bradypodidae & Brown-throated Sloth & 05 Bradypus variegatus \\
\hline \multicolumn{4}{|l|}{ Birds } \\
\hline Anseriforme & Anatidae & $\begin{array}{l}\text { White-faced duck } \\
\text { Black-bellied Whistling- } \\
\text { duck }\end{array}$ & $\begin{array}{l}28 \text { Dendrocygna viduata } \\
18 \text { Dendrocygna autumnalis }\end{array}$ \\
\hline \multirow{10}{*}{ Psittaciforme } & \multirow{10}{*}{ Psittacidae } & White-winged Parakeet & 04 Brotogeris versicolurus \\
\hline & & Golden Parakeet & 03 Guaruba guarouba \\
\hline & & Peach-fronted Parakeet & 02 Eupsittula aurea \\
\hline & & Orange-winged Amazon & 23 Amazona amazonica \\
\hline & & Turquoise-fronted Amazon & 22 Amazona aestiva \\
\hline & & White-eyed Parakeet & 02 Aratinga leucophthalmus \\
\hline & & Scarlet Macaw & 02 Ara macao \\
\hline & & Blue-winged Macaw & 03 Ara maracana \\
\hline & & Scaly-headed Parrot & 01 Pionus menstruus \\
\hline & & Scaly-headed Parrot & 01 Pionus maximiliani \\
\hline \multirow[t]{4}{*}{ Strigiforme } & Tytonidae & Common Barn-owl & 07 Tyto Alba \\
\hline & \multirow{3}{*}{ Strigidae } & Tropical Screech-owl & 02 Megascops choliba \\
\hline & & Striped Owl & 01 Asio clamator \\
\hline & & Burrowing Owl & 02 Speotyto cunicularia \\
\hline \multirow{7}{*}{ Passeriforme } & \multirow{6}{*}{ Fringilidae } & Purple-throated Euphonia & 03 Euphonia chlorotica \\
\hline & & Lined Seedeater & 05 Sporophila lineola \\
\hline & & Campo Troupial & 05 Icterus jamacaii \\
\hline & & White-lined Tanager & 01 Thachyphonus rufus \\
\hline & & Chopi Blackbird & 01 Gnorimopsar chopi \\
\hline & & Yellow-rumped Cacique & 01 Cacicus cela \\
\hline & Sturnidae & Tropical Mockingbird & 05 Mimus gilvus \\
\hline \multirow{3}{*}{ Piciforme } & \multirow{3}{*}{ Ramphastidae } & Channel-billed Toucan & 06 Ramphastos vitelinus \\
\hline & & Red-billed Toucan & 01 Ramphastos tucanus \\
\hline & & Spot-billed Toucanet & 01 Selenidera maculirostris \\
\hline
\end{tabular}


Table 3 - Parasites (eegs and oocysts) in wild animals from the Center for Screening of Wild Animals of São Luis, Maranhão State (CETAS/MA), Brazil, from August/2006 to July/2008.

\begin{tabular}{|c|c|c|c|}
\hline Animals & $\begin{array}{c}\text { Number of } \\
\text { positive samples }\end{array}$ & Species & Parasites (eggs/oocysts)* \\
\hline \multicolumn{4}{|c|}{ Birds } \\
\hline \multirow{4}{*}{ Pool } & 04 & Dendrocygna viduata & $\begin{array}{l}\text { oocysts of coccidia , Ascaridia sp. Dispharynx } \\
\text { sp. }\end{array}$ \\
\hline & 04 & Amazona amazonica & \multirow{3}{*}{$\begin{array}{l}\text { oocysts of5uiolkjgfghrtyuighlkjujm 'kujytgrttyg } \\
\text { coccidia e Ascaridia sp. }\end{array}$} \\
\hline & 03 & Amazona aestiva & \\
\hline & 01 & Ara maracana & \\
\hline Individual & 05 & Tyto Alba & oocysts of coccidia \\
\hline Pool & 03 & Dendrocygna autumnalis & Echinostoma sp., Ascaridia $\mathrm{sp}$ \\
\hline Individual & 01 & Sporophila lineola & oocysts of coccidia \\
\hline Individual & 01 & Ramphastos toco & oocysts of coccidia \\
\hline \multicolumn{4}{|c|}{ Mammals } \\
\hline Individual & 06 & Leopardus tigrinus & Spirometra sp. \\
\hline Individual & 04 & Leopardus pardalis & Trichuris vulpis \\
\hline Individual & 02 & Puma yagouaroundi & Trichuris vulpis \\
\hline Pool & 04 & Nasua nasua & Strongyloides sp., eggs of the hookworm type \\
\hline Pool & 02 & Cerdocyon thous & $\begin{array}{l}\text { eggs of the hookworm type, oocysts of } \\
\text { coccidia }\end{array}$ \\
\hline Individual & 05 & Saimiri sciureus & $\begin{array}{l}\text { eggs of the hookworm type, Ascaris sp., } \\
\text { taenídeo }\end{array}$ \\
\hline Individual & 15 & Sapajus apella & $\begin{array}{l}\text { eggs of the hookworm type, Ascaris sp., } \\
\text { Strongyloidea }\end{array}$ \\
\hline Pool & 05 & Sapajus apella & $\begin{array}{l}\text { eggs of the hookworm type, Ascaris sp., } \\
\text { oocysts of coccidia, Capillaria sp., taenídeo, } \\
\text { Strongyloidea }\end{array}$ \\
\hline Individual & 03 & Agouti paca & Strongyloides sp., eggs of the hookworm type. \\
\hline Individual & 02 & Tamandua tetratactyla & eggs of the hookworm type \\
\hline Individual & 01 & Mazana gouazoubira & Strongyloides sp. \\
\hline \multicolumn{4}{|c|}{ Reptiles } \\
\hline Individual & 01 & Iguana iguana & Capillaria sp. \\
\hline Individual & 03 & Boa constrictor & oocysts of coccidia \\
\hline
\end{tabular}

\section{DISCUSION}

The biodiversity can be composed by different co-evolutionary process in a variety of taxonomic levels (Ehrlich; Raven, 1964; Margulis, 1971; Hamilton et al., 1990; Thompson, 2009), including parasites. They suffer selective pressure along with their hosts (co-evolution) so when they came to extinction their parasites are extinct as well (Thompson, 2009).

The study of the parasitic fauna of domestic and wild animals have much more emphasis in the species that causes economic loss and zoonosis and parasites that have effect on wild fauna are not a priority (Thompson et al., 2010). However, importance should be given to parasitic fauna of wild animals housed in captivity such as the ones from zoo and center of conservation.
The release of animals housed in captivity for a long time decrease their immunological capacity to react to great majority of natural pathogens from animals of the same species in a natural environment (Wyatt et al., 2008). Additionally, the impact of human proximity and anthropic action upon the wild environment and consequently to their pathogens is not well stablished (Thompson et al., 2010).

In the present study the eggs of the hookworm type and Strongyloides were the most frequent in fecal samples of mammals. Eggs of the hookworm type were identified in samples from primates, carnivore, rodents and xenarthrans. This helminth has direct life cycle, the infective third larva stage is very active. In domestic canids and felids it is the most common gender observed (Bowman, 2014) and the most pathogenic species cause anemia and weight loose (Fortes, 1993), it is also common in wild animals (Santos et al., 2015; Kouassi et al., 2015). Ancylostoma, one of the most 
important geohelminth, causes environmental contamination and zoonosis such as cutaneous larva migrans and eosinophilic enteritis in humans. The pathogenicity of the adult worm depends on the parasite load and host age (Bowman, 2014).

The genus Strongyloides was identified in samples of mammals (primates, carnivores and artiodactyls), the same reported in Alopex lagopus by Aguirre et al. (2000) and in carnivores and artiodactyls by Freitas et al. (2001). The greatest number of positive samples for Strongyloides was in primates. It could be explained by the fact that the third infective stage of this genus has the capacity of active penetration so animals can be re-infected or infected themselves by entering in contact with contaminated soil (Fortes, 1993). Infection by Strongyloides sp. taenid (Hymenolepis sp.) in samples from primates have been reported (Gonzalo et al., 1990; Arrojo, 2002), as observed in the present study since we also identified taenid eggs in four samples of Neotropical primates. The genus Strongyloides infect numerous vertebrate, such as snakes, felids, canids and ruminants (Dorris et al., 2002). In Brazil, species of this genus have been reported infecting a wide diversity of hosts (Vicent et al., 1997) as the first report of the occurrence of Strongyloides in Leopardus trigrinus in the Botucatu, State of São Paulo by Santos et al. (2009)

Eggs of Spirometra sp. were detected in samples from L. tigrinus, it is a common finding in carnivores, birds and amphibians. These animals generally feed on crustaceans, the intermediate host. This parasite has dogs, cats and raccoons as its definitive hosts (Bowman, 2014) and can determine a zoonosis called sparganosis (Mentz et al., 2011). The infection by Spirometra was also reported in Puma concolor and Panthera onca in Perú (TANTALEÁN; Michaud, 2005), in Leopardus colocolo in Brazil (Gresseler at al., 2016) and other felids, as observed by Khatun et al. (2014), in lions in captive condition in Bangladesh and snakes (Almeida et al., 2016).

Trichuris vulpis was identified in samples from $L$. pardalis and $P$. yagouaroundi in the present study. This parasite was reported in wild felids in captive in the State of Santa Catarina, Brazil (Muller et al., 2005). Species of the family Trichuridae were reported in Leopardus colocolo by Gresseler et al. (2016) in the State of São Paulo. Trichuris vulpis has a short period of maturation in the environment ( 9 to 10 days) becoming infective in short time enabling re-infection (Fortes, 1993).

Birds were infected by Dispharynx, Ascaridia, Echinostoma, besides coccidian as previously reported by Freitas et al. (2002) in the State of Pernambuco, Brazil. Ascaridia was the most frequent finding along with coccidia. Ascaridia is the most common gastrointestinal helminth in captive birds. It has been reported in exotic birds in the State of Sergipe, Brazil (Lima et al., 2016). This parasite causes deficient absorption, weight loose, anorexia and diaarrhea. It has also been described causing intussusception, occlusion and death (Ritchie et al., 1994). It is common in Psittaciformes birds being identified in all orders of birds sampled in the present study. In CETAS of João
Pessoa, State of Paraíba, Brazil, Ascaridia was recovered by necropsy of Psittaciformes birds as causa mortis intestinal due to intestinal obstruction (Melo et al., 2013). According to Snak et al. (2012) taenid eggs were prevalent in captive birds in Paraná State, Brazil, however this eggs were identified in the present study.

Coccidian are common intestinal parasites in birds. Here we detected non sporulated oocysts all orders of birds sampled; however they were more prevalent in Anseriformes. In Brazil toucans in captivity are frequently found infected (Benez, 2004). Generally it is necessary to make intense work of erradication in places where coccidan are present since they are resistant to environmental condition, besides they have direct life cycle that enables the persistence of infected animals (Benez, 2004). They are also identified in co-infection with nematodes (Lima et al., 2016), as demonstrated in the present study in pools of Dendrocygna viduata, Amazona amazônica, Amazona aestiva e Ara maracana (oocysts coccidian and Ascaridia).

According to Junker et al. (2015) coccidiosis is a disease of intensification due to the build-up of the sporulated oocysts in accumulated feces, facilitating ingestion of large infective doses. A further fact is immunosuppression of host, due to stress. This is particularly relevant in free-ranging wild animals brought in captivity, even temporarily.

Dispharynx is a common nematode on wild birds and birds reared in extensive system (turkey, free-range chicken and guinea fowls). Their habitat in the host is the proventriculus and gizzard (Bartmann; Amato, 2009). Eggs of this parasite were detected in Anseriformes. The pathology caused by this parasite is more severe in young animals and influences their growth (Ritchie et al., 1994; Bartmann; Amato, 2009).

In reptiles, the number of gastrointestinal infection was low and oocysts of coccidian were identified in three B. constrictor and Capillaria sp. in an I. iguana. Infections by coccidia are very common in free reptiles and the majority of the cases are of low or none pathogenicity. The infected animals present the intestinal epithelium health or with few lesions, they recovery is fast enough so they are asymptomatic (RaśNoryńska; Sokól, 2015). Protozoan of the Eimeria gender are found in the biliary ducts and gall-bladder of reptiles while Isospora is found mainly in the intestine (Raś-Noryńska; Sokół, 2015). According to Rataj et al. (2011) Capillaria is a common finding in reptiles, however it was not identified here.

It should be emphasizes that reptiles became increasingly common domestic pets. In wild, they rarely come into contact with their own waste or uneaten food, which is a common occurrence in captive (Dovc et al., 2004) favoring contact with contaminated materials.

The samples that were analyzed by the sedimentation method of Hoffmann et al. (1934) presented a more satisfactory results when compared to the results obtainded by the use of the flotation method of Willis (1927) since it detected a greater number of positive samples as observed by Cerqueira et al. (2007) in comparing the sensibility both methods in 
diagnosing ancilostomid eggs. Similarly, Freitas et al. (2001; 2002) verified that the sedimentation method was more efficient to detect eggs, oocysts and cysts in the feces of wild mammals and birds under captive conditions.

It can be concluded that wild animals act as hosts of different species of parasites and the knowledge of the richness parasitic fauna in the Centers for Screening of Wild Animals is an excellent alternative to perform ex situ studies as well important for controlling and preventing parasitic diseases.

\section{ACKNOWLEDGEMENTS}

To Cetas' staff, specially Dr. Roberto Rodrigues Veloso Junior. To Conselho Nacional de Desenvolvimento Científico e Tecnológico ( $\boldsymbol{C N P q})$ for the financial support by means of the schorlarship.

\section{REFERÊNCIAS}

ALMEIDA, G.G., COSCARELLI, D., MELO, M.N., MELO, A.L., PINTO, H.A. Molecular identification of Spirometra spp. (Cestoda: Diphyllobothriidae) in some wild animals from Brazil. Parasitology International, Amsterdam, v. 65 , p. 428-431, 2016.

AGUIRRE, A. A.; ANGERBJORN, A.; TANNERFELDT, M.; MORNER, T. Health evaluation of artic fox (Alopex lagopus) cubs in Sweden. Journal of Wildlife Medicine, Yulee, v. 31, n. 1, p. $36-40,2000$.

ALEXANDRE, M. Épidémiologie des zoonoses parasitaires majeures au Brésil: synthése bibliographique. Revue de Médecine Vétérinaire, Toulouse, v. 6, n. 151, p. 485-492, 2000.

ARROJO, L. Parásitos de animales silvestres en cativerio en Lima, Perú. Revista Peruana de Biologia, Lima, v. 2, n. 9, p. 118-120, 2002.

BARTMANN, A.; AMATO, S. B. Dispharynx nasuta (Nematoda: Acuariidae) em Guira guira e Crotophaga ani (Cuculiformes: Cuculidae) no estado do Rio Grande do Sul, Brasil. Ciência Rural, Santa Maria, v. 39, n. 4, p. 1141-1147, 2009.

BENEZ, S. M. Aves: criação, clínica, teoria, prática: silvestres, ornamentais e avinhados. 4 ed. Ribeirão Preto: Tecmedd, 2004. p. 385-396.

BOIA, M. N.; MOTTA, L. P.; SALAZAR, M. S. P.; MUTIS, M. P. S.; COUTINHO, R. B. A.; COURA J. R. Estudo das parasitoses intestinais e da infecção chagásica no Município de Novo Airão, estado do Amazonas, Brasil. Cadernos de Saúde Pública, Rio de Janeiro, v. 15, n. 3, p. 497-504, 1999.
BOWMAN, D. D. Georgis' parasitology for veterinarians. 10 ed. Phildelphia: Saunders, 2014. 496 p.

CARMO, A. M.; SALGADO, C. A. Ocorrência de parasitos intestinais em Callithrix sp. (Mammalia, Primates, Callithrichidae). Revista Brasileira de Zoociências, Juiz de Fora, v. 5, n. 2, p. 267-272, 2003.

CATÃO-DIAS J.L. Doenças e seus impactos sobre a biodiversidade. Ciência e Cultura, Campinas, v. 55, p. 32-34, 2003.

CERQUEIRA, E. J. L.; ARCANJO, M. S.; ALCANTARA, L. M. Análise comparativa da sensibilidade da técnica de Willis, no diagnostico parasitológico de ancilostomíase. Diálogo e Ciência, São Paulo, v. 5, n. 10, p. 1-7, 2007.

COSTA MACEDO, L. M.; REY, L. Aleitamento e parasitismo materno-infantil. Revista da Sociedade Brasileira de Medicina Tropical, Uberaba, v. 33, n. 4, p. 371-375, 2000.

EHRLICH, P. R.; RAVEN, P. H. Butterflies and plants: a study in coevolution. Evolution, New York, v. 18, n. 4 , p. 586-608, 1964.

FELASA. Health monitoring of non-human primate colonies. Laboratory Animals, London, n, 33, suplemento 1, S1-S16. 1999.

FIGUEIREDO, M. A. P.; SANTOS, A. C. G.; GUERRA, R. M. S. N. C. Ectoparasitos de animais silvestres no Maranhão. Pesquisa Veterinária Brasileira, Seropédica, v. 30, n. 11, p. 988-990, 2010.

FORTES, E. Parasitologia veterinária. 2 ed. São Paulo: Ícone, 1993. 606 p.

FREITAS, M. F. L.; OLIVEIRA, J. B.; CAVALCANTE, M. D. B.; OLIVEIRA, R. V. Y.; LEITE, A. S.; MAGALHÃES, V. S.; SOBRINHO, A. E. Parasitos gastrointestinales de aves silvestres en cautiveiro en el estado de Pernambuco, Brasil. Parasitologia Latinoamericana, Santiago, v. 57, n. 12, p. 50-54, 2002.

FREITAS, M. F. L.; OLIVEIRA, J. B.; CAVALCANTE, M. D. B.; OLIVEIRA, R. V. Y.; SOBRINHO, A. E. Perfil coproparasitológico de mamíferos silvestres en cautiveiro en el estado de Pernambuco, Brasil. Parasitologia al Día, Santiago, v. 25, n. 3-4, p. 121-125, 2001.

GONZALO, A.; AQUINO, R.; MONTOYA, E. Prevalencia de parásitos gastrointestinales en Aotus nancymai capturados en la Amazonía peruana. In: La primatologia en el Perú, investigaciones primatológica (1973-1985). 1 ed. Lima: Proyecto Peruano de Primatologia, 1990. p. 544-554. 
GOULART, C. E. S. Herpetologia, herpetocultura e medicina de répteis. 1 ed. Rio de Janeiro: L. F. Livros de Veterinária, 2004. 330 p.

GUERRA, R. M. S. N. C.; SILVA, A. L. A.; SERRAFREIRE, N. M. Amblyomma rotundatum (Acari: Ixodidae) in Kinosternon scorpioides (Chelonia: Kinosternidae) in Maranhão state, Brasil. Entomologia y Vectores, Rio de Janeiro, v. 7, n. 3, p. 335-338, 2000 .

HAMILTON, W. D.; AXELROD, R.; TANESE, R. Sexual reproduction as an adaptation to resist parasites (a review). Proceedings of the National Academy of Sciences, Washington, v. 87, n. 9, p. 3566-3573, 1990.

HOFFMANN, W. A.; PONS, J. A.; JANER, J. L. The sedimentation concentration method in Schistossomiase mansoni Puerto Rico. Journal of Public Health Tropical Medicine, Aberdeen, v. 9, p. 283-298, 1934.

KHATUN, M. M.; BEGUM, N.; MAMUN, M. A. A.; MONDAL M. M. H.; SHAKIF-UL-AZAM, M. Coprological study of gastrointestinal parasites of captive animals at Rangpur Recreational Garden and Zoo in Bangladesh. Journal of Threatened Taxa, Rajasthan, v. 6, n. 8, p. 6142-6147, 2014.

KOUASSI, R. Y. W.; MCGRAW, S. W.; YAO, P. K.; ABOU-BACAR, A.; BRUNET, J.; PESSON, B.; CANDOLFI, E. Diversity and prevalence of gastrointestinal parasites in seven non-human primates of the Taï National Park, Côte d'Ivoire. Parasite, Les Ulis, v. 22, p. 1, 2015.

LEWINSOHN, T. M.; PRADO, P. I. Biodiversidade brasileira: síntese do estado atual do conhecimento. São Paulo: Contexto, 2002. Versão eletrônica.

LI, M.; ZHAO, B.; LI, B.; WANG, Q.; NIU, L.; DENG, J.; GU, X.; PENG, X.; WANG, T.; YANG, G. Prevalence of gastrointestinal parasites in captive nonhuman primates of twenty-four zoological gardens in China. Journal of Medical Primatology, Copenhagen, v. 44, n. 3, p. 168-173, 2015.

LIM, Y.; NGUI, R.; SHUKRI, J.; ROHELA, M.; MAT NAIM, H. R. Intestinal parasites in various animals at a zoo in Malaysia. Veterinary Parasitolology, Amsterdam, v. 157, n. 1-2, p. 154-159, 2008.

LIMA, V. F. S.; BEZERRA, T. L.; ANDRADE, A. F.; RAMOS, R. A. N.; FAUSTINO, M. A. G.; ALVES, L. C.; MEIRA-SANTOS, P. O. Gastrointestinal parasites of exotic birds living in captivity in the state of Sergipe, Northeastern Brazil. Brazilian Journal of Veterinary Parasitology, Jaboticabal, v. 26, n. 1, p. 96-99, 2017.

MACKENSTEDT, U.; JENKINS, D.; ROMIG, T. The role of wildlife in the transmission of parasitic zoonoses in peri-urban and urban areas. International
Journal for Parasitology: Parasites and Wildlife, Amsterdam, v. 4, n. 1, p. 71-79, 2015.

MARGULIS, L. Symbiosis and evolution. Scientific American, New York, v. 225, n. 2, p. 48-57, 1971.

MARIETTO-GONÇALVES, G. A.; MARTINS, T. F.; LIMA, E. T.; LOPES, R. S.; ANDREATTI FILHO, R. L. Prevalência de endoparasitas em amostras fecais de aves silvestres e exóticas examinadas no Laboratório de Ornitopatologia e no laboratório de Enfermidades Parasitárias da FMVZ-UNESP/Botucatu, SP. Ciência Animal Brasileira, Goiânia, v. 10, n. 1, p. 349-354, 2009.

MARQUES, S. M. T.; BANDEIRA, C.; QUADROS, R. M. Prevalência de enteroparasitoses em Concórdia, Santa Catarina, Brasil. Parasitologia Latinoamericana, Santiago, n 1-2, v. 60, p. 78 - 81, 2005.

MELO, C. M. F.; OLIVEIRA, J. B.; FEITOSA, T. F.; ATHAYDE, A. C. R.; DANTAS, A. F. M.; MENEZES, D. J. A.; VILELA, V. L. R.; WAGNER, P. G. C.; FEBRÔNIO, A. B. Parasites of Psittaciformes and Accipitriformes in Paraíba state, northeastern Brazil. Revista Brasileira de Parasitologia Veterinária, Jaboticabal, v. 22, n. 2, p. 314-317, 2013.

MENTZ, Márcia Bohrer; PROCIANOY, Fernando; MAESTRI, Marcelo Krieger and ROTT, Marilise Brittes.Human ocular sparganosis in southern Brazil. Revista do Instituto de Medicina tropical de São Paulo. v. 53, n. 1, p.51-53, 2011.

MULlER, G. C. K.; GREINERT, J. A.; SILVA FILHO, H. H. Frequência de parasitas intestinais em felinos mantidos em zoológicos. Arquivo Brasileiro de Medicina Veterinária e Zootecnia, Belo Horizonte, v. 57, n. 4, p. 559-561, 2005.

MUNEME, E.; OTSYULA, M.; MBAABU, D. A. N.; MUTAHI, W. T.; MURIUKI, S. M. K.; MUCHEMI, G. M. Helminth and protozoan gastrointestinal tract parasites in captive and wild-trapped african nonhuman primates. Veterinary Parasitology, Amsterdam. v. 78, n. 3, p. 195-201. 1998.

RAŚ-NORYŃSKA, M.; SOKÓŁ, R. Internal parasites of reptiles. Annals of Parasitology, Warsaw, v. 61, n. 2, p. 115-117, 2015.

RATAJ, A. V.; LINDTNER-KNIFIC, R.; VLAHOVIĆ, K.; MAVRI, U.; DOVČ, A. Parasites in pet reptiles. Acta Veterinaria Scandinavica, Copenhagen, v. 53, n. 1, p. 33, 2011.

RITCHIE, B. W.; HARRISON, G. J.; HARRISON, L. R. Avian medicine: principles and application. Lake Worth: Wingers Publishing, 1994. 840 p. 
SANTANA, A.C.; MESQUITA, E.F.M; SEIXAS FILHO, J.T. Revista Semioses, Rio de Janeiro, v 8, n. $1,2014$.

SANTOS, P. M. S.; SILVA, S. G. N.; FONSECA, C. F.; OLIVEIRA, J. B. Parasitos de aves e mamíferos silvestres em cativeiro no estado de Pernambuco. Pesquisa Veterinária Brasileira, Rio de Janeiro, v. 35, n. 9, p. 788-794, 2015.

SCOTT, M. E. The impact of infection and disease on animal populations: implications for conservation biology. Conservation Biology, San Francisco, v. 2, n. 1, p. 40-56, 1988.

SKRYABIN, K. I. Key to parasitic nematodes. Jerusalem: IPST Press Binding; 1969. vol. 1. Spirurata and filariata.

SNAK, A.; LENZI, P. F.; AGOSTINI, K. M.; DELGADO, L. E.; MONTANUCCI, C. R.; ZABOTT, M. V. Análises coproparasitológicas de aves silvestres cativas. Ciência Animal Brasileira, Goiânia, v. 15, n. 4, p. 502-507, 2014.

SOULSBY, E. J. L. Helminths, Arthropods \& Protozoa of domesticated animals. London: Baillière, Tindall and Cassell, 1968.

TANTALEÁN, M.; MICHAUD, C. Huéspedes definitivos de Spirometra mansonis (Cestoda, Diphyllobothriidae) en el Perú. Revista Peruana de Biologia, Lima, v. 12, n. 1, p. 153-157, 2005.

THOMPSON, J. N. The coevolving web of life. The American Naturalist, Chicago, v. 173, n. 2, p. 125140, 2009.

THOMPSON, R. C.; ALYMBERY, A. J.; SMITH, A. Parasites, emerging disease and wildlife conservation. International Journal for Parasitology, Amsterdam, v. 40, n. 10 , p. $1163-1170,2010$.
UICN. Guías para reintroducciones de la UICN. Preparadas por el Grupo de Especialistas en Reintroducción de la Comisión de Supervivencia de Especies de la UICN, UICN, Gland, Suiza y Cambridge, Reino Unido. 1998. p. 20.

VIEIRA, F. M.; LIMA, S. D.; BESSA, E. C. Morphology and biometry of eggs and larvae of Strongyloides sp. Grassi, 1879 (Rhabditoidea: Strongyloididae), a gastrointestinal parasite of Hydrochaeris hydrochaeris (Linnaeus, 1766) (Rodentia: Hydrochaeridae), in the municipality of Juiz de Fora, Minas Gerais, Brazil. Revista Brasileira de Parasitologia, Jaboticabal. v. 1, n. 15, p. 7-12, 2006.

WILLIS, H. H. A simple levitation method for the detection of hookworm ova. Medical Journal Australia, Sydney, v. 2, n. 18, p. 375-376, 1921.

WYATT, K. B.; CAMPOS, P. F.; GILBERT, M. T. P.; KOLOKOTRONIS, S. O.; HYNES, W. H.; DESALLE, R.; DASZAK, P.; MACPHEE, R. D. E.; GREENWOOD, A. D. Historical mammal extinction on Christmas Island (Indian Ocean) correlates with introduced infectious disease. PLoS One, San Francisco, v. 3, n. e3602, 2008.

YAMAGUTI, S. Systema Helminthum 3. The nematodes of vertebrates Part 1: 1-697, Part II: 681 1261, 102 pls. 909 figs. New York: Interscience Publishers Inc. 1961. 